\title{
PEMODELAN AUTOREGRESSIVE FRACTIONALLY INTEGRATED MOVING AVERAGE DENGAN EFEK EXPONENTIAL GARCH (ARFIMA-EGARCH) UNTUK PREDIKSI HARGA BERAS DI KOTA SEMARANG
}

\author{
Rezky Dwi Hanifa ${ }^{1}$, Mustafid ${ }^{2}$, Arief Rachman Hakim ${ }^{3}$ \\ 1,2,3 Departemen Statistika, Fakultas Sains dan Matematika, Universitas Diponegoro \\ email: rezkydwihanifa@gmail.com
}

\begin{abstract}
Time series data is a type of data that is often used to estimate future values. Long memory phenomenon often occurs in time series data. Long memory is a condition that shows a strong correlation between observations even though they are quite far away. This phenomenon can be overcome by modeling time series data using the Autoregressive Fractional Integrated Moving Average (ARFIMA) model. This model is characterized by a fractional difference value. ARFIMA (Autoregressive Fractional Integrated Moving Average) model assumes that the residuals are normally distributed, mutually independent, and homogeneous. However, usually in financial data, the residual variants are not constant. This can be overcome by modeling variants. Standard equipment that can be used to model variants is the ARCH / GARCH (Auto Regressive Conditional Heteroscedasticity / Generalized Auto Regressive Conditional Heteroscedasticity) model. Another phenomenon that often occurs in GARCH models is the leverage effect on the residuals of the model. EGARCH (Exponential General Auto Regessive Conditional Heteroscedasticity) is a development of the GARCH model that is appropriate for data that has an leverage effect. The implementation of this model is by modeling financial data, so this study takes 136 monthly data on rice prices in Semarang City fromJanuary 2009 to April 2020. The purpose of this study is to create a long memory data forecasting model using the Exponential method. Generalized Autoregressive Conditional Heteroscedasticity (EGARCH). The best modelobtained is ARFIMA $(1, \mathrm{~d}, 1)$ EGARCH $(1,1)$ which is capable of forecasting with a MAPE value of $3.37 \%$.
\end{abstract}

Keyword : Rice price, forecasting, long memory, leverage effect, GARCH, EGARCH

\section{PENDAHULUAN}

Beras menjadi salah satu komoditas yang strategis baik di aspek ekonomi, sosial, maupun politik. Selain itu, beras menjadi makanan pokok yang menjadi sumber utama asupan kalori. Maka stabilitas harga berasi menjadi salah satu aspek yang terus dipantau oleh pemerintah karena harga beras memberi kontribusi pada ketahanan pangan, kemiskinan, stabilitas makro ekonomi, dan pertumbuhan ekonomi. Peramalan menjadi solusi yang bisa digunakan untuk melakukan pemantauan harga beras dengan melakukan prediksi harga beras di masa mendatang. Menurut Makridakis et al. (1999) peramalan terbagi menjadi dua yaitu peramalan kualitatif berdasarkan pendapat para ahli dan peramalan kuantitatif menggunakan metode statistika.

Peramalan runtun waktu dapat dilakukan dengan menggunakan beberapa metode populer seperti Autoregressive Integrated Moving Average (ARIMA), exponential smoothing, dekomposisi atau regresi. Pendekatan metode ini efisien untuk peramalan time series, namun masih ada kekurangan ketika adanya fluktuasi yang ekstrim pada data runtun waktu. Fenomena lain yang sering terjadi pada data time series adalah data bersifat long memory. Menurut Kartikasari (2015) long memory adalah fenomena pada data runtun waktu yang merupakan kondisi dimana setiap observasi memiliki korelasi yang cukup kuat dengan observasi lain walaupun jarak tiap observasi cukup jauh. Kartikasari (2015) menjelaskan bahwa ARFIMA (Autoregressive Fractional Integrated Moving Average) digunakan untuk data yang mengikuti proses linear long memory. 
Model ARFIMA (Autoregressive Fractional Integrated Moving Average) memiliki asumsi bahwa residual berdistribusi normal, saling bebas, dan homogen. Namun pada data finansial seringkali muncul kasus bahwa varian dari error tidak konstan, dengan kata lain data mengalami heteroskedastisitas. Untuk mengatasi hal ini, peralatan standar yang digunakan adalah model ARCH/GARCH (Auto Regessive Conditional Heteroscedasticity/ Generalized Auto Regessive Conditional Heteroscedasticity). Salah satu pengembangan model ini adalah model EGARCH (Exponential Generalized Auto Regessive Conditional Heteroscedasticity). Model ini tidak memiliki syarat kestasioneran seperti ARCH/GARCH, sehingga tepat digunakan pada data yang memiliki efek asimetris. Efek asimetris terjadi jika terdapat korelasi antara standar residual kuadrat dari model ARFIMA, dengan lag standar residual model GARCH.

\section{TINJAUAN PUSTAKA}

\subsection{Analisis Runtun Waktu}

Model-model runtun waktu pada dasarnya menggunakan data masa lalu untuk memprediksi permintaan di masa depan. Model mengasumsikan bahwa setiap titik data permintaan yang diamati terdiri dari beberapa komponen sistematis dan beberapa komponen acak. Model deret waktu dirancang untuk memprediksi komponen sistematis tetapi bukan komponen acak. Idenya mirip dengan logika bagan kendali mutu karena peneliti tidak perlu melakukan perubahan akan variabilitas proses selama masih dalam batas kendali. Mengubah model runtun waktu karena kesalahan yang acak hanya akan meningkatkan kesalahan dalam ramalan masa depan. (Montgomery et al., 2008)

\subsection{Stasione ritas}

Box dan Jenkins (1976) menjelaskan bahwa pada deret waktu yang bersifat stasioner kuat, waktu pengamatan tidak berpengaruh terhadap rata-rata $\mu$, variansi $\sigma^{2}$ dan kovariansi $\gamma_{\mathrm{k}}$. ini berarti bahwa deret $X_{\mathrm{t}}$ akan berfluktuasi di sekitar $\mu$ dan dan variansi $\sigma^{2}$ yang tetap, dan dapat dikatakan bahwa deret $X_{t}$ stasioner dalam $\mu$ dan $\sigma^{2}$ (Wei, 2006). Menurut Ekananda (2014), suatu data runtun waktu dikatakan stasioner dalam variansi jika struktur data dari waktu ke waktu mempunyai fluktuasi dengan varian yang tetap atau konstan dari waktu ke waktu. Montgomery et al.(2008) mendefinisikan varian yang konstan sebagai :

$$
\sigma_{z}^{2}=\operatorname{var}(z)=\int_{-\infty}^{\infty}\left(z-\mu_{z}\right)^{2} f(z) d z
$$

Menurut Ekananda (2014) Data bersifat stasioner pada nilai tengahnya (mean) yaitu apabila data berfluktuasi di sekitar suatu nilai tengah yang tetap sepanjang/selama waktu observasi. Sedangkan menurut Montgomery et al.(2008), stasioneritas menyatakan keseimbangan dan stabilitas pada data, dimana rata-rata yang konstan dapat didefinis ikan sebagai :

$$
\mu=\mathrm{E}\left(z_{t}\right)=\int_{-\infty}^{\infty} z_{t} p\left(z_{t}\right) d z
$$

dengan $\quad \mathrm{z}_{\mathrm{t}}$ : data ke $\mathrm{t}$

$\mu$ : rata-rata

$\mathrm{p}\left(\mathrm{z}_{\mathrm{t}}\right)$ : distribusi probabilitas 
Stasioneritas dalam mean ini dapat diuji melalui uji akar unit (Unit Root Test). Salah satu metode uji akar unit adalah metode Augmented Dickey Fuller(ADF). Model persamaan secara umum adalah sebagai berikut :

$$
\Delta z_{t}=\beta z_{t-1}+\sum_{j=1}^{p-1} \phi_{j} \Delta z_{t-j}+a_{t}
$$

Keterangan :

$\beta:$ koefisien

$z_{t}$ : nilai variabel pada waktu ke $\mathrm{t}$

$\phi$ : konstanta

$a_{t}$ :residual pada waktu ke $\mathrm{t}$

\subsection{Model Autoregressive Fractionally Integrated Moving Average (ARFIMA)}

Model Autoregressive Fractionally Integrated Moving Average (ARFIMA) merupakan proses yang termasuk dalam jenis model long memory, dimana memiliki tujuan untuk menjelaskan secara eksplisit adanya korelasi jangka panjang pada data (Contretas,2012). Dalam Contreras (2012) dituliskan bahwa secara umum, proses ARFIMA(p,d,q) dapat dinotasikan dalam persamaan :

$$
\phi_{p}(B) z_{t}=\theta_{q}(B)(1-B)^{-d} a_{t}
$$

Dimana

$$
\phi_{p}(B)=1-\phi_{1} B-\cdots-\phi_{p} B^{p}
$$

Dan

$$
\theta_{q}(B)=1-\theta_{1} B-\cdots-\theta_{q} B^{q}
$$

Serta $\phi_{p}(B)$ dan $\theta_{q}(B)$ tidak memiliki akar unit, B merupakan operator backshift. Lalu (1 $B)^{-d}$ merupakan operator differensi fraksional dari ekspansi binomial.

$$
(1-B)^{-d}=\sum_{j=0}^{\infty} \frac{(j+d) !}{(j+1) !(d) !} B^{j}=\sum_{j=0}^{\infty}\left(\begin{array}{l}
d \\
j
\end{array}\right) B^{j}
$$

Untuk $\mathrm{a}_{\mathrm{t}}$ white noise dengan mean nol dan varian $\sigma^{2}$.

\subsection{Pola Long Memory}

Proses long memory merupakan sifat observasi yang memiliki korelasi kuat meskipun jarak waktu antar observasi jauh . ACF proses long memory akan turun secara lambat membentuk pola hiperbolik. Qian dan Rasheed (2004) menjelaskan bahwa sifat dari ketergantungan jangka panjang dapat dibuktikan dengan cara menghitung nilai statistik Hurst berdasarkan nilai R/S. Nilai Hurst ditentukan dengan menentukan rata-rata z yaitu :

$$
\bar{z}=\frac{1}{n} \sum_{t=1}^{n} z_{t}
$$

Kemudian menentukan Adjusted Mean:

Dan simpangan baku

$$
Z_{t}^{a d j}=z_{t}-\bar{z}
$$

$$
s_{t}=\sqrt{\sum_{t=1}^{n} \frac{\left(z_{t}-\vec{z}\right)^{2}}{n}}
$$

Selanjutnya adalah menentukan deviasi kumulatif 
Dengan rentang dari deviasi kumulatif :

$$
z_{t}^{*}=\sum_{t=1}^{n} Z_{t}^{a d j}
$$

$$
R_{t}=\max \left(Z_{1}^{*}, Z_{2}^{*}, \ldots, Z_{t}^{*}\right)-\min \left(Z_{1}^{*}, Z_{2}^{*}, \ldots, Z_{t}^{*}\right)
$$

Nilai Hurst diperoleh dengan melogaritmakan statistik $\mathrm{R} / \mathrm{S}$ dan ditaksir dengan metode Ordinary Least Square $(O L S)$. Apabila nilai $\mathrm{H}=0.5$ maka data deret waktu bersifat acak. Jika $0<\mathrm{H}<0.5$ maka data bersifat short memory, sedangkan long memory ditunjukkan apabila nilai $\mathrm{H}$ berada pada interval $0.5<\mathrm{H}<1$.

\subsection{Pengujian Asumsi Model}

Uji normalitas residual dilakukan untuk melihat kenormalan dari residual. Model dikatakan baik jika residual berdistribusi normal terjadi jika histogram residual memiliki kecenderungan membentuk pola lonceng. Secara formal, dapat diuji menggunakan uji hipotesis, dengan statistika uji yaitu salah astunya dengan nilai Kolmogorov-Smirnov.

Dengan :

$$
D=\operatorname{Sup}\left|S(x)-F_{0}(x)\right|
$$

$\mathrm{S}(\mathrm{x})$ : fungsi peluang kumulatif yang dihitung dari data sampel

$\mathrm{F}_{0}(\mathrm{x})$ : fungsi peluang kumulatif dari distribusi normal

Sup : Nilai supremum untuk semua $\mathrm{x}$ dari $\left|S(x)-F_{0}(x)\right|$

Proses white noise terjadi jika bentuk peubah acak yang berurutan tidak saling berkorelasi dan mengikuti distribusi tertentu. Proses white noise adalah stasioner dengan beberapa sifat yaitu $E\left(a_{t}\right)=\mu_{a}=0, \operatorname{Var}\left(a_{t}\right)=\sigma^{2}$ dan $\gamma_{k}=\operatorname{cov}\left(a_{t}, a_{t+k}\right)=0$ untuk k tidak sama dengan 0. (Wei, 2006)

$$
Q=n(n+2) \sum_{i=1}^{k}(n-k)^{-1} \hat{\rho}_{k}^{2}
$$

Q : statistik uji Ljung-Box

$\rho_{\mathrm{k}}$ : autokorelasi residual pada lag ke-k

$\mathrm{n}$ : banyaknya pengamatan

$\mathrm{k}$ : maksimum lag

Uji non heteroskedastisitas digunakan untuk menguji homogenitas ragam dari residual. Suatu proses $z_{t}$ bersifat heteroskedastisitas ketika variansi bersyarat $\operatorname{var}\left(z_{t} \mid z_{t-1}, z_{t-2}, \ldots\right)$ tidak konstan dari waktu ke waktuatau $\sigma_{t}=\sqrt{\operatorname{var}\left(z_{t} \mid z_{t-1}, z_{t-2}, \ldots\right)}$ berubah dari waktu ke waktu (Posedel,2005). Uji Lagrange Multiplier (LM) digunakan untuk mendeteksi adanya proses ARCH/GARCH dengan cara meregresikan kuadrat dari residual model (Tsay,2005).

\subsection{Model Exponential Generalized Autoregressive Conditional Heteroscedasticity}

Salah satu pengembangan dari GARCH yaitu model EGARCH yang sering digunakan untuk analisis data yang berada dalam kondisi asimetris. EGARCH oleh Nelson (1991) dengan variansi dirumuskan sebagai berikut :

$$
\ln \left(\sigma_{t}^{2}\right)=a+\sum_{i=1}^{r} b_{i} \ln \left(\sigma_{t-i}^{2}\right)+\sum_{j=1}^{s} c_{j} \frac{e_{t-j}}{\sigma_{t-j}}+\sum_{j=1}^{s} d_{j}\left(\left|\frac{e_{t-j}}{\sigma_{t-j}}\right|+E\left(\frac{e_{t-j}}{\sigma_{t-j}}\right)\right)
$$


Dengan $\sigma_{t}^{2}$ variasi error pada waktu $t, e_{t}$ error pada waktu $t$, a konstanta, dan $b, c, d$ parameter.

Tagliafichi (2003) menjelaskan bahwa untuk memeriksa keberadaan pengaruh leverage effect (efek asimetris) salah satunya dengan cara memodelkan data runtun waktu dengan GARCH terlebih dahulu, lalu diuji apakah memiliki efek asimetris dengan melihat korelasi antara standar residual kuadrat dari model ARFIMA, dengan lag standar residual model GARCH dengan menggunakan korelasi silang.

\subsection{Model Terbaik}

Model terbaik juga dapat ditentukan dengan melihat nilai Akaike's Information Criterion (AIC) yang diperkenalkan oleh Akaike pada tahun 1973. Metode ini mempertimbangkan banyaknya parameter yang digunakan dalam model. Model ini muncul karena menganggap bahwa model yang baik tidak cukup hanya dengan menggunakan nilai MSE terkecil, namun juga harus memenuhi prinsip parsimony(kesederhanaan). Dalam Paridi(2019), dituliskan bahwa penghitungan nilai AIC adalah sebagai brikut :

$$
A I C=n \ln \hat{\sigma}^{2}+2 M
$$

Dengan $\mathrm{M}$ merupakan banyaknya paramtr yang diduga.

Untuk mengetahui seberapa baik kinerja suatu model yang diperoleh digunakan nilai Mean Absolute Percentage Error (MAPE). MAPE berguna untuk mengindikasikan seberapa besar kesalahan dalam proses peramalan yang dilakukan dibandingkan dengan nilai aktualnya. MAPE dapat dihitung dengan

$$
M A P E=\frac{1}{n} \sum_{t=1}^{n}\left|\frac{\left(z_{t}-\hat{z}_{t}\right)}{z_{t}}\right| x 100 \%
$$

Keterangan :

$\mathrm{n}$ : banyak pengamatan

$z_{t}$ : data aktual

$\hat{z}_{t}:$ data ramalan

\section{METODOLOGI PENELITIAN}

\subsection{Jenis dan Sumber Data}

Jenis data yang digunakan dalam penelitian ini berupa data sekunder yaitu data yang diperoleh dari sumber yang sudah ada. Sumber dari data ini yaitu dari Dinas Perindustrian dan Perdagangan Provinsi Jawa Tengah sebanyak 136 data bulanan harga beras di Kota Semarang dari Januari 2009 sampai dengan tahun April 2020.

\subsection{Langkah Analis is}

Langkah analisis data yang dilakukan dalam penulisan ini adalah sebagai berikut :

1. Menguji stasioneritas data dengan plot time series

2. Melakukan transformasi jika ada data yang tidak stasioner dalam variasi.

3. Membuat plot ACF dan PACF

4. Melakukan perhitungan Hurst dengan metode R/S untuk melihat efek long memory.

5. Melakukan estimasi nilai d dengan GPH estimator

6. Melakukan differensi menggunakan nilai d yang sudah ditentukan

7. Membuat plot ACF dan PACF menggunakan data yang sidah di differensi

8. Melakukan pemodelan dengan metode ARFIMA 
9. Melakukan uji asumsi dengan uji independensi residual, normalitas, serta uji non heteroskedastisitas.

10. Melakukan identifikasi model GARCH dan estimasi model GARCH

11. Uji asimetris data dengan uji sign bias

12. Identifikasi, estimasi dan verifikasi model EGARCH

13. Menentukan model terbaik EGARCH

14. Melakukan peramalan harga beras untuk 12 tahap kedepan dengan model ARFIMAEGARCH yang terbaik

15. Melakukan evaluasi kriteria model dilihat dari nilai MAPE

\section{HASIL DAN PEMBAHASAN}

\subsection{Deskripsi Data}

Data yang digunakan dalam penelitian ini adalah data harga beras di Kota Semarang sebanyak 136 data, yaitu data bulanan dari bulan Januari 2009 sampai dengan April 2020. nilai harga beras cenderung naik dengan fluktuasi yang tidak terlalu tinggi. Nilai harga beras maksimum adalah Rp 11.561 yang terjadi pada bulan Januari 2018 sedangkan harga beras minimum bernilai Rp 5.360 terjadi pada bulan April 2009. Sehingga range dari data yaitu 6.204. kemudian rata-rata dari data adalah $\mathrm{Rp} 8.430$ dengan variansi 2.688.756,1 dan standar deviasi sebesar 1.639,7427.

\subsection{Stasioneritas Data}

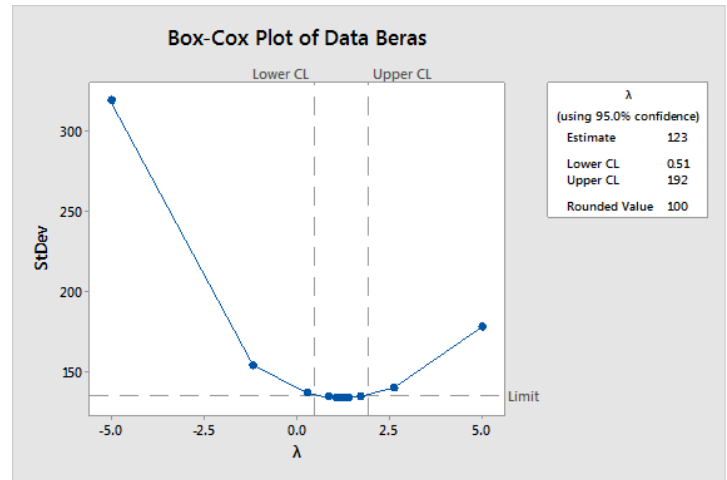

Gambar 1. Box-Cox Transformation Test

Gambar 1 diatas menunjukkan bahwa nilai rounded value data harga beras adalah 1 . Hal ini menunjukkan bahwa data stasioner dalam varian.

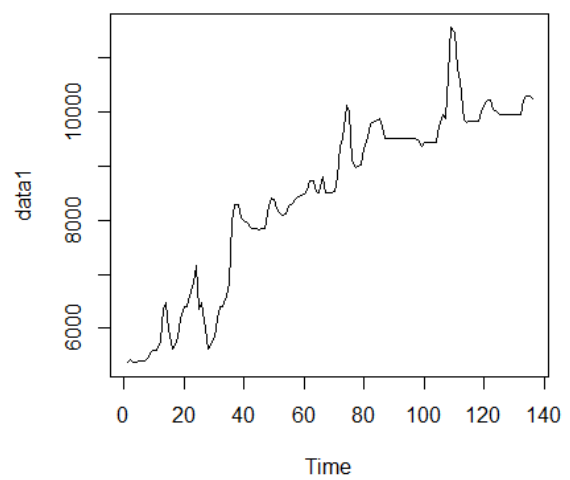

Gambar 2. Time Series Plot 
Gambar 2 diatas menunjukkan bahwa data harga beras memiliki trend naik. Semakin banyak nilai t (waktu) maka harga beras akan semakin meningkat. Secara visual, data harga beras tidak stasioner dalam mean. Selanjutnya dilakukan pengujian stasioneritas dalam mean secara formal dengan metode Augmented Dickey-Fuller Test. Didapatkan nilai $p$-value = 0.4204 , sehingga pada taraf signifikansi $\alpha=5 \%$, dapat disimpulkan bahwa ada akar unit atau data tidak stasioner dalam mean.

\subsection{Pengujian Pola Long Memory}

Qian dan Rasheed(2004) menjelaskan bahwa sifat dari ketergantungan jangka panjang dapat dibuktikan dengan cara menghitung nilai statistik Hurst berdasarkan nilai R/S. Jika nilai Hurst terletak pada interval $0,5<\mathrm{H}<1$ maka dapat disimpulkan bahwa terdapat memori jangka panjang pada data. Untuk menghitung nilai $\mathrm{H}$, digunakan metode Rescaled Range Statistics $(R / S)$ dengan langkah sebagai berikut :

1. Menghitung rata-rata data

$$
\bar{z}=\frac{1}{T} \sum_{t=1}^{T} z_{t}=\frac{1146452}{136}=8430
$$

2. Menghitung rata-rata tertimbang dari masing-masing data

$$
\begin{gathered}
Z_{1}^{a d j}=z_{1}-\bar{z}=5381-8430=-3049 \\
Z_{2}^{a d j}=z_{2}-\bar{z}=5430-8430=-3000 \\
\vdots \\
Z_{136}^{a d j}=z_{136}-\bar{z}=10243-8430=1813
\end{gathered}
$$

3. Menghitung simpangan baku masing-masing data

$$
\begin{gathered}
s_{1}=\sqrt{\sum_{t=1}^{T} \frac{\left(z_{t}-\bar{z}\right)^{2}}{T}}=3048,8 \\
s_{2}=\sqrt{\sum_{t=1}^{2} \frac{\left(z_{t}-\bar{z}\right)^{2}}{2}}=3024,4 \\
s_{136}=\sqrt{\sum_{t=1}^{120} \frac{\left(z_{t}-\bar{z}\right)^{2}}{120}}=1633.7
\end{gathered}
$$

4. Menghitung simpangan kumulatif data

$$
\begin{gathered}
z_{1}^{*}=\sum_{t=1}^{1} Z_{t}^{a d j}=Z_{1}^{a d j}=-3049 \\
z_{2}^{*}=\sum_{t=1}^{2} Z_{t}^{a d j}=Z_{1}^{a d j}+Z_{2}^{a d j}=-6049 \\
\vdots \\
z_{136}^{*}=\sum_{t=1}^{120} Z_{t}^{a d j}=Z_{1}^{a d j}+Z_{2}^{a d j}+\cdots+Z_{120}^{a d j}=0
\end{gathered}
$$

5. Menghitung rentangan data

$$
\begin{aligned}
& R_{1}=\max \left(Z_{1}^{*}\right)-\min \left(Z_{1}^{*}\right)=-3049-(-3049)=0 \\
& R_{2}=\max \left(Z_{1}^{*}, Z_{2}^{*}\right)-\min \left(Z_{1}^{*}, Z_{2}^{*}\right)
\end{aligned}
$$




$$
\begin{aligned}
& =-3049-(-6049)=3000 \\
& R_{136}=\max \left(Z_{1}^{*}, Z_{2}^{*}, \ldots, Z_{120}^{*}\right)-\min \left(Z_{1}^{*}, Z_{2}^{*}, \ldots, Z_{120}^{*}\right) \\
& \quad=0-(-92798)=92798
\end{aligned}
$$

6. Menghitung rescaled range statistics $(R / S)$

$$
\begin{gathered}
\left(\frac{R}{S}\right)_{1}=\frac{R_{1}}{S_{1}}=\frac{0}{3048.8}=0 \\
\left(\frac{R}{S}\right)_{2}=\frac{R_{2}}{S_{2}}=\frac{3000}{3024.4}=0.99186643 \\
\vdots \\
(R / S)_{136}=\frac{R_{120}}{S_{120}}=\frac{92798}{1633.7}=56.8
\end{gathered}
$$

7. Menghitung nilai log rescaled range statistics $(R / S)$

$$
\begin{gathered}
\mathrm{Y}_{1}=\ln \left[(R / S)_{1}\right]=1 \\
\mathrm{Y}_{2}=\ln \left[(R / S)_{2}\right]-0.008166828 \\
\vdots \\
\mathrm{Y}_{136}=\ln \left[(R / S)_{136}\right]=4.039573429
\end{gathered}
$$

8. Menghiung log waktu dari pengamatan

$$
\begin{gathered}
\mathrm{X}_{1}=\ln (1)=0 \\
\mathrm{X}_{2}=\ln (2)=0.693147181 \\
\vdots \\
\mathrm{X}_{136}=\ln (136)=4.912654886
\end{gathered}
$$

9. Menghitung nilai Hurst Exponent $(H)$

$$
H=\frac{\sum_{t=1}^{n}\left(X_{t}-\mu_{X_{t}}\right)\left(Y_{t}-\mu_{Y_{t}}\right)}{\sum_{t=1}^{n}\left(X_{t}-\mu_{X_{t}}\right)^{2}}=0.7724
$$

Berdasarkan nilai Hurst Exponent $(\mathrm{H})$ yang telah dilakukan yaitu sebesar 0.7724. Karena nilai Hurst Exponent terletak pada interval $0,5<\mathrm{H}<1$, maka dapat disimpulkan bahwa terdapat memori jangka panjang pada data.

\subsection{Es timasi Parame ter (d)}

Metode yang digunakan dalam menentukan nilai paramter pe,beda (d) adalah metode Gaweke Porter-Hudak (GPH) estimator. Estimasi nilai d ini dilakukan mengunakan sofware R. diperoleh nilai d sebesar 0.9415964. Kembali dilakukan pengecekan untuk menguji apakah estimasi nilai parameter d sudah tepat. Uji formal dilakukan dengan menggunakan Augmented Dickey-Fuller Test didapatkan nilai $p$-value $=0.01$, sehingga pada taraf signifikansi $\alpha=5 \%$, dapat disimpulkan bahwa ada akar unit atau data stasioner dalam mean.

\subsection{Identifikasi Model}


Series diff1

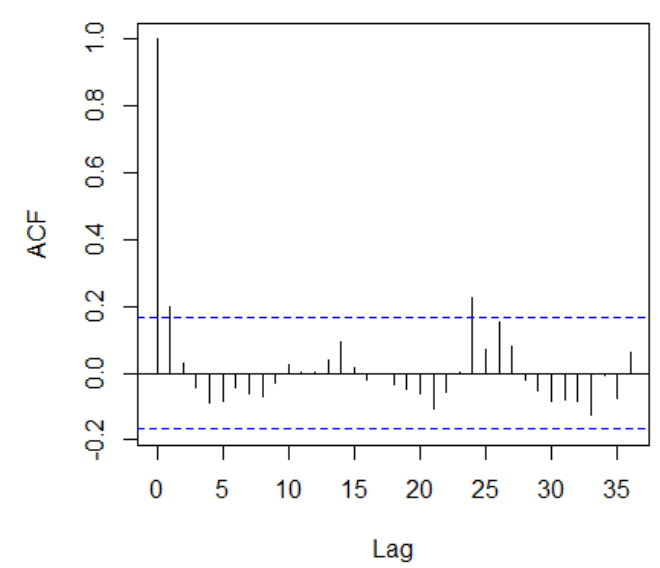

Gambar 3. Plot Fungsi Autokorelasi Data Harga Beras
Series diff1

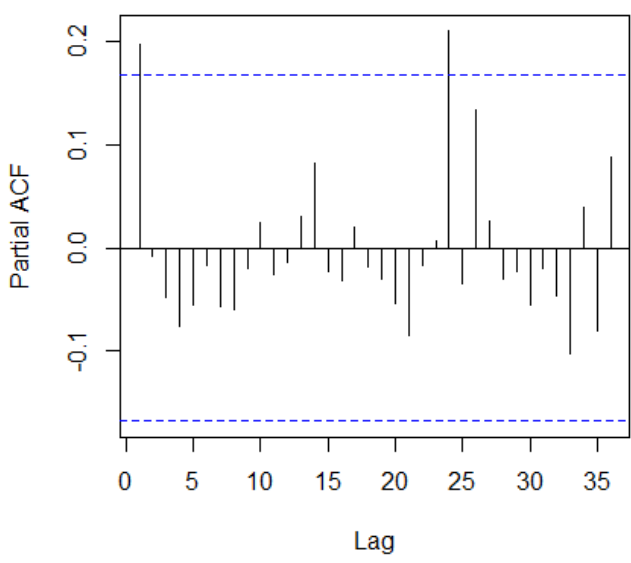

Gambar 4. Plot Fungsi Autokorelasi Parsial Data Harga Beras

- Model ARFIMA yang mungkin adalah $\operatorname{ARFIMA}(0, \mathrm{~d}, 1), \operatorname{ARFIMA}(0, \mathrm{~d},[24])$, $\operatorname{ARFIMA}(1, \mathrm{~d}, 0), \quad \operatorname{ARFIMA}(1, \mathrm{~d}, 1), \quad \operatorname{ARFIMA}(1, \mathrm{~d},[24]), \quad \operatorname{ARFIMA}([24], \mathrm{d}, 0)$, $\operatorname{ARFIMA}([24], d, 1)$, dan ARFIMA([24],d,[24])

\subsection{Model Terbaik ARFIMA}

Tabel 1. Tabel Pemilihan Model Terbaik

\begin{tabular}{|c|c|c|c|c|c|}
\hline Model & $\begin{array}{l}\text { Signifikansi } \\
\text { Parameter }\end{array}$ & White Noise & $\begin{array}{c}\text { Kesamaan } \\
\text { varian }\end{array}$ & Normalitas & $\mathrm{AIC}$ \\
\hline ARFIMA $(0, d, 1)$ & $\begin{array}{c}\text { Parameter } \\
\text { signifikan }\end{array}$ & $\begin{array}{c}\text { Proses } \\
\text { white noise }\end{array}$ & $\begin{array}{c}\text { Varian tidak } \\
\text { sama }\end{array}$ & $\begin{array}{c}\text { Tidak } \\
\text { berdistribusi } \\
\text { normal }\end{array}$ & 2674.53 \\
\hline $\operatorname{ARFIMA}(0, \mathrm{~d},[24])$ & $\begin{array}{c}\text { Parameter } \\
\text { signifikan }\end{array}$ & $\begin{array}{c}\text { Proses } \\
\text { white noise }\end{array}$ & $\begin{array}{c}\text { Varian tidak } \\
\text { sama }\end{array}$ & $\begin{array}{c}\text { Tidak } \\
\text { berdistribusi } \\
\text { normal }\end{array}$ & 2729.32 \\
\hline ARFIMA $(1, \mathrm{~d}, 0)$ & $\begin{array}{c}\text { Parameter } \\
\text { signifikan }\end{array}$ & $\begin{array}{l}\text { Proses } \\
\text { tidak white } \\
\text { noise }\end{array}$ & $\begin{array}{c}\text { Varian tidak } \\
\text { sama }\end{array}$ & $\begin{array}{c}\text { Tidak } \\
\text { berdistribusi } \\
\text { normal }\end{array}$ & 1909.26 \\
\hline $\operatorname{ARFIMA}(1, \mathrm{~d}, 1)$ & $\begin{array}{c}\text { Parameter } \\
\text { signifikan }\end{array}$ & $\begin{array}{c}\text { Proses } \\
\text { white noise }\end{array}$ & $\begin{array}{c}\text { Varian tidak } \\
\text { sama }\end{array}$ & $\begin{array}{c}\text { Tidak } \\
\text { berdistribusi } \\
\text { normal }\end{array}$ & 1895.87 \\
\hline ARFIMA(1,d,[24]) & $\begin{array}{c}\text { Parameter } \\
\text { signifikan }\end{array}$ & $\begin{array}{c}\text { Proses } \\
\text { white noise }\end{array}$ & $\begin{array}{c}\text { Varian tidak } \\
\text { sama }\end{array}$ & $\begin{array}{c}\text { Tidak } \\
\text { berdistribusi } \\
\text { normal }\end{array}$ & 1978.63 \\
\hline ARFIMA([24],d,0) & $\begin{array}{l}\text { Parameter } \\
\text { signifikan }\end{array}$ & $\begin{array}{c}\text { Proses } \\
\text { white noise }\end{array}$ & $\begin{array}{c}\text { Varian tidak } \\
\text { sama }\end{array}$ & $\begin{array}{c}\text { Tidak } \\
\text { berdistribusi } \\
\text { normal }\end{array}$ & 2403.22 \\
\hline ARFIMA([24],d,1) & $\begin{array}{c}\text { Parameter } \\
\text { signifikan }\end{array}$ & $\begin{array}{c}\text { Proses } \\
\text { white noise }\end{array}$ & $\begin{array}{c}\text { Varian tidak } \\
\text { sama }\end{array}$ & $\begin{array}{c}\text { Tidak } \\
\text { berdistribusi } \\
\text { normal }\end{array}$ & 2244.65 \\
\hline
\end{tabular}




\begin{tabular}{|c|c|c|c|c|c|}
\hline $\begin{array}{c}\text { ARFIMA } \\
\text { ([24],d,[24]) }\end{array}$ & $\begin{array}{r}\text { Parameter } \\
\text { signifikan }\end{array}$ & $\begin{array}{c}\text { Proses } \\
\text { white noise }\end{array}$ & $\begin{array}{c}\text { Varian tidak } \\
\text { sama }\end{array}$ & $\begin{array}{c}\text { Tidak } \\
\text { berdistribusi } \\
\text { normal }\end{array}$ & 2374.94 \\
\hline
\end{tabular}

Hasil analisis pada Tabel 1 menunjukkan bahwa model terbaik dari semua model yang ada yaitu ARFIMA(1,d,1) dengan persamaan awal:

$$
\begin{gathered}
\phi_{p}(B)(1-B)^{d} z_{t}=\delta+\theta_{q}(B) a_{t} \\
\left(1-\phi_{1} B\right)(1-B)^{d} z_{t}=\left(1-\theta_{1} B\right) a_{t} \\
(1-921.85 B)(1-B)^{0.9415964} z_{t}=(1-4.33 B) a_{t}
\end{gathered}
$$

Namun pada model ini terdapat efek Arch/Garch sehingga perlu domedekan ARCH/GARCH.

\begin{tabular}{|c|c|c|c|c|c|}
\hline Model & Parameter & $\begin{array}{c}\text { Estimasi } \\
\text { Parameter }\end{array}$ & z-Statistic & $p$-value & AIC \\
\hline \multirow{5}{*}{ GARCH $(1,1)$} & $\phi_{1}$ & $5.7991 \mathrm{e}-01$ & 7.70667 & 0.000000 & \multirow{5}{*}{14.397} \\
\hline & $\theta_{1}$ & $1.0916 \mathrm{e}-01$ & 1.08127 & 0.279579 & \\
\hline & c & $1.6168 \mathrm{e}+04$ & 2.71780 & 0.006572 & \\
\hline & $\alpha_{1}$ & $1.0000 \mathrm{e}+00$ & 3.40394 & 0.000664 & \\
\hline & $\beta_{1}$ & $6.3726 \mathrm{e}-02$ & 0.91747 & 0.358897 & \\
\hline \multirow{6}{*}{ GARCH $(1,2)$} & $\phi_{1}$ & 0.50561 & 2.3278 & 0.019925 & \multirow{6}{*}{14.477} \\
\hline & $\theta_{1}$ & -0.61347 & -4.0727 & 0.000046 & \\
\hline & $\mathrm{c}$ & 12032.95346 & 3.3466 & 0.000818 & \\
\hline & $\alpha_{1}$ & 0.92334 & 4.3581 & 0.000013 & \\
\hline & $\beta_{1}$ & 0.23022 & 3.2885 & 0.001007 & \\
\hline & $\beta_{2}$ & 0.00000 & 0.0000 & 1.000000 & \\
\hline \multirow{6}{*}{$\operatorname{GARCH}(2,1)$. } & $\phi_{1}$ & -0.95000 & -29.6035 & 0.000000 & \multirow{6}{*}{14.406} \\
\hline & $\theta_{1}$ & 0.94110 & 27.8540 & 0.000000 & \\
\hline & $\mathrm{c}$ & 14646.97672 & 4.4746 & 0.000008 & \\
\hline & $\alpha_{1}$ & 0.75835 & 3.2705 & 0.001074 & \\
\hline & $\alpha_{2}$ & 0.47543 & 3.0222 & 0.002509 & \\
\hline & $\beta_{1}$ & 0.00000 & 0.0000 & 1.000000 & \\
\hline \multirow{7}{*}{$\operatorname{GARCH}(2,2)$} & $\phi_{1}$ & 0.99189 & 458.1245 & 0.000000 & \multirow{7}{*}{14.388} \\
\hline & $\theta_{1}$ & -0.98316 & -288.4039 & 0.000000 & \\
\hline & $\mathrm{c}$ & 13194.18708 & 4.3331 & 0.000015 & \\
\hline & $\alpha_{1}$ & 1.00000 & 3.5798 & 0.000344 & \\
\hline & $\alpha_{2}$ & 0.41098 & 3.0649 & 0.002177 & \\
\hline & $\beta_{1}$ & 0.00000 & 0.0000 & 1.000000 & \\
\hline & $\beta_{2}$ & 0.00000 & 0.0000 & 1.000000 & \\
\hline
\end{tabular}

\subsection{Identifikasi Model GARCH}

Tabel 2. Tabel Identifikasi Model GARCH

Tabel 2 menunjukkan bahwa model yang memiliki nilai AIC minimum yaitu ARFIMA(1,d,1) - GARCH $(2,2)$ sebesar 14.388. Sehingga model terbaik GARCH yaitu ARFIMA(1,d,1) - GARCH $(2,2)$ dengan persamaan sebagai berikut :

$$
(1-0.99189 B)(1-B)^{0.9415964} z_{t}=(1+0.98316 B) a_{t}
$$


Dengan

$$
\sigma_{t}^{2}=13194.18708+\varepsilon_{t-1}^{2}+0.41098 \varepsilon_{t-2}^{2}
$$

Uji asimetrisperludilakukan untuk mengetahui apakah ada efek asimetris pada model. Keberadaan pengaruh leverage effect (efek asimetris) dapat diperiksa dengan cara Uji Sign Bias.

$\mathrm{H}_{0}: \varphi_{1}=\varphi_{1}=\varphi_{2}=\varphi_{3}=0$ (residual bersifat simetris)

$\mathrm{H}_{1}$ : paling sedikit ada satu $\varphi_{j} \neq 0$, untuk $\mathrm{j}=1,2,3$ (residual bersifat asimetris)

Taraf signifikansi yang digunakan adalah $5 \%$

Statistik uji :

$F=\frac{S S R_{0} / k}{\frac{S S R_{1}}{n}-k-1}=57.6898$

$p$-value $=1.831 \mathrm{e}-12$

Kriteria uji :

Menolak $\mathrm{H}_{0}$ jika $\mathrm{F}_{\text {hitung }}>\mathrm{F}_{(\alpha ; \mathrm{k}, \mathrm{n}-\mathrm{k}-1)}$ atau $\mathrm{p}$-value $<\alpha$

Keputusan :

Nilai $p$-value $=1.831 \mathrm{e}-12<\alpha(0.05)$, sehingga $\mathrm{H}_{0}$ ditolak.

Kesimpulan :

Pada taraf signifikansi 5\%, model ARFIMA(1,d,1) - GARCH $(2,2)$ memiliki residual dengan efek asimetris, karena nilai $p$-value $=1.831 \mathrm{e}-12<\alpha(0.05)$ sehingga perlu dilanjutkan dengan pemodelan EGARCH untukmenghilangkan efek asimetris.

\subsection{Idenifikasi Model EGARCH}

Tabel 3. Tabel Identifikasi Model EGARCH

\begin{tabular}{cccccc}
\hline Model & Parameter & $\begin{array}{c}\text { Estimasi } \\
\text { Parameter }\end{array}$ & z-Statistic & p-value & AIC \\
& $\phi_{1}$ & 0.639734 & 6.77936 & 0.000000 & \\
& $\theta_{1}$ & 0.176742 & 1.96200 & 0.049762 & \\
ARFIMA(1,d,1) - & $\mathrm{C}(3)$ & 5.674759 & 4.83989 & 0.000001 & \multirow{2}{*}{14.361} \\
EGARCH $(1,1)$ & $\mathrm{C}(4)$ & -0.056819 & -0.40955 & 0.682134 & \\
& $\mathrm{C}(5)$ & 0.487387 & 4.59660 & 0.000004 & \\
& $\mathrm{C}(6)$ & 0.852299 & 4.90110 & 0.000001 & \\
\hline & $\phi_{1}$ & 0.681515 & 11.32956 & 0.000000 & \\
ARFIMA(1,d,1) - & $\theta_{1}$ & -0.748924 & -15.36169 & 0.000000 & \\
EGARCH $(1,2)$ & $\mathrm{C}(3)$ & 2.408521 & 3.95448 & 0.000077 & \\
& $\mathrm{C}(4)$ & 0.445533 & 3.47268 & 0.000515 & 14.391 \\
& $\mathrm{C}(5)$ & 0.802697 & 4.89766 & 0.000001 & \\
& $\mathrm{C}(6)$ & -0.038292 & -0.23016 & 0.817964 & \\
& $\mathrm{C}(7)$ & 0.299163 & 2.34041 & 0.019262 & \\
\hline ARFIMA(1,d,1) & $\phi_{1}$ & -0.533170 & $-2.2841 \mathrm{e}+01$ & 0.000000 & \\
EGARCH $(2,1)$ & $\theta_{1}$ & 0.635346 & $1.4209 \mathrm{e}+01$ & 0.000000 & \\
& $\mathrm{C}(3)$ & 1.137531 & $2.2796 \mathrm{e}+01$ & 0.000000 & 14.368 \\
& $\mathrm{C}(4)$ & 0.946574 & $4.8132 \mathrm{e}+00$ & 0.000001 & \\
& $\mathrm{C}(5)$ & -0.349674 & $-2.5360 \mathrm{e}+00$ & 0.011213 &
\end{tabular}




\begin{tabular}{cccccc} 
& $\mathrm{C}(6)$ & 0.878456 & $2.1934 \mathrm{e}+05$ & 0.000000 & \\
& $\mathrm{C}(7)$ & 0.007061 & $2.4998 \mathrm{e}-02$ & 0.980057 & \\
$\mathrm{C}(8)$ & 0.063538 & $2.3713 \mathrm{e}-01$ & 0.812554 & \\
\hline & $\phi_{1}$ & -0.547690 & -16.5223 & 0.000000 & \\
& $\theta_{1}$ & 0.677032 & 23.4852 & 0.000000 & \\
ARFIMA(1,d,1) - & $\mathrm{C}(3)$ & 4.152264 & 4.3630 & 0.000013 & \\
EGARCH $(2,2)$ & $\mathrm{C}(4)$ & 0.572408 & 3.7861 & 0.000153 & \\
& $\mathrm{C}(5)$ & 0.523619 & 4.8626 & 0.000001 & 14.382 \\
& $\mathrm{C}(6)$ & -0.180804 & -3.7048 & 0.000212 & \\
& $\mathrm{C}(7)$ & 0.755713 & 14.8276 & 0.000000 & \\
& $\mathrm{C}(8)$ & -0.033737 & -0.2617 & 0.793552 & \\
& $\mathrm{C}(9)$ & 0.290362 & 2.4267 & 0.015235 & \\
\hline
\end{tabular}

Tabel 3 diatas menunjukkan bahwa model ARFIMA(1,d,1) - EGARCH (1,1) memiliki nilai AIC terkecil yatu sebesar 14.361. Hal ini menunjukkan bahwa model terbaik yang didapatkan yaitu ARFIMA(1,d,1) EGARCH $(1,1)$. Model akhir yang didapatkan yaitu :

dengan

$$
(1-0.639734 B)(1-B)^{0.9415964} z_{t}=(1+0.176742 B) a_{t}
$$

dan model varian :

$$
a_{t} \sim N\left(0, \sigma_{t}^{2}\right)
$$

$$
\ln \left(\sigma_{t}^{2}\right)=5.674759+0.487387 \frac{e_{t-1}}{\sigma_{t-1}}+0.852299 \ln \left(\sigma_{t-1}^{2}\right)
$$

Pengujian efek ARCH/GARCH perlu dilakukan ulang untuk memastikan bahwa varian residual model telah konstan. Uji Lagrange Multiplier (LM) digunakan untuk mendeteksi adanya proses ARCH/GARCH menggunakan Uji Sign Bias. Uji hipotesis yang dilakukan adalah sebagai berikut :

a. Hipotesis

H0 : $\alpha_{1}=\alpha_{2}=\cdots=\alpha_{k}=0$ (tidak ada efek ARCH/GARCH pada residual sampai lag ke-k)

H0 : Paling sedikit ada satu $\alpha_{\mathrm{i}} \neq 0, \mathrm{i}=1,2, \ldots, \mathrm{k}$ (ada efek ARCH/GARCH pada residual sampai lag ke-k)Taraf Signifikansi $\alpha=5 \%$

b. Statistik Uji

$$
\begin{gathered}
L M=\frac{\left(S S R_{0}-S S R_{1}\right) / k}{S S R_{1} /(n-2 k-1)}=16.512 \\
p \text {-value }=0.1689
\end{gathered}
$$

c. Kriteria penolakan

$\mathrm{H}_{0}$ ditolak jika nilai $\mathrm{LM}>x_{(\propto, m)}^{2}$, atau $p$-value $<\alpha$

d. Keputusan

$\mathrm{H}_{0}$ diterima karena nilai $p$-value $=0.1689>\alpha=0.05$

e. Kesimpulan

Pada taraf signifikansi $\alpha=5 \%$, tidak terdapat efek heteroskedastisitad pada residual dari model ARFIMA(1,d,1) EGARCH $(1,1)$ karena nilai $p$-value $>\alpha$.

Hasil uji LM diatas menunjukkan bahwa setelah dimodelkan dengan EGARCH, efek heteroskedastisitas menjadi hilang.

\subsection{Pe ramalan}


Peramalan dilakukan sebanyak 12 tahap kedepan. Data yang dimodelkan sebelumnya telah dilakukan transformasi dalam bentuk kuadrat, maka setelah diperoleh hasil peramalan harus dikembalikan ke bentuk asli dari data dengan cara melakukan akar pada data hasil peramalan. Data hasil peramalan ditunjukkan pada tabel 4 sebagai berikut :

Tabel 4. Tabel Nilai Ramalan

\begin{tabular}{ccc}
\hline Tahun & Bulan & Nilai Ramalan \\
\hline 2020 & Mei & 10207 \\
2020 & Juni & 10183 \\
2020 & Juli & 10165 \\
2020 & Agustus & 10151 \\
2020 & September & 10140 \\
2020 & Oktober & 10131 \\
2020 & November & 10123 \\
2020 & Desember & 10115 \\
2021 & Januari & 10108 \\
2021 & Februari & 10101 \\
2021 & Maret & 10095 \\
2021 & April & 10088 \\
\hline
\end{tabular}

Nilai MAPE dapat dihitung dengan :

$$
\begin{gathered}
\text { MAPE }=\frac{1}{n} \sum_{t=1}^{n}\left|\frac{\left(z_{t}-\hat{z}_{t}\right)}{z_{t}}\right| \times 100 \% \\
M A P E=\frac{1}{136} \sum_{t=1}^{136}\left|\frac{\left(z_{t}-\hat{z}_{t}\right)}{z_{t}}\right| \times 100 \% \\
M A P E=\frac{1}{9}\left[\left|\frac{5381-0}{5381}\right|+\left|\frac{5430-9460}{5430}\right|+\cdots+\left|\frac{10243-10273}{10243}\right|\right] x 100 \% \\
=3,37 \%
\end{gathered}
$$

Nilai MAPE tersebut menunjukkan bahwa model memiliki kemampuan peramalan yang sangat baik.

\section{KESIMPULAN}

Data harian harga beras Kota Semarang dari tahun 2009 sampai dengan 2020 memiliki pola long memory yang ditunjukkan dengan plot ACF turun secara hiperbolik dan nilai Hurst sebesar 0.7. Nilai differensi yang diperoleh dari hasil estimasi dengan metode GPH sebesar 0.9415964. Model ARFIMA terbaik dari data yaitu ARFIMA(1,d,1) dengan persamaan sebagai berikut :

$$
(1-0.99189 B)(1-B)^{0.9415964} z_{t}=(1+0.98316 B) a_{t}
$$

Terdapat efek asimetris GARCH pada residual model sehingga dilakukan pemodelan varian dengan model EGARCH. Didapatkan bahwa model terbaik yaitu ARFIMA(1,d,1) $\operatorname{EGARCH}(1,1)$ dengan persamaan sebagai berikut :

$$
(1-0.639734 B)(1-B)^{0.9415964} z_{t}=(1+0.176742 B) a_{t}
$$

dengan,

$$
a_{t} \sim N\left(0, \sigma_{t}^{2}\right),
$$


dan,

$$
\ln \left(\sigma_{t}^{2}\right)=5.674759+0.487387 \frac{e_{t-1}}{\sigma_{t-1}}+0.852299 \ln \left(\sigma_{t-1}^{2}\right)
$$

dengan nilai MAPE sebesar 3,37 \% yang dapat dikatakan bahwa peramalan memiliki kemampuan peramalan yang sangat baik.

\section{DAFTAR PUSTAKA}

Ekananda, M. 2014. Analisis Data Time Series untuk Penelitian Ekonomi, Manajemen, dan Akuntansi. Jakarta : Mitra Wacana Media.

Kartikasari, P. 2015. Studi Simulasi Pengaruh Outlier terhadap Pengujian Linieritas dan Long Memory beserta Aplikasinya pada Data Return Saham. Tesis. Surabaya : Institut Teknologi Sepuluh Nopember

Makridakis, S., Wheelwright, S.C., dan McGree, V.E. 1999. Metode dan Aplikasi Peramalan. Edisi kedua. Jilid 1. Jakarta : Binarupa Aksara.

Montgomery, D.C., Jennings, C.L., dan Kulahci, M. 2008. Introduction to Time Series Analysis and Forecasting. Canada : John Wiley \& Sons Inc.

Box, G.E.P., and Jenkins, G.M. 1976. Time Series Analysis Forecasting and Control. Second Edition. Holden-Day, San Fransisco.

Wei, W. W.S. 2006. Time Series Analysis : Univariate and Multivariate Methods. Amerika : Pearson Education, Inc

Qian, B. dan Rasheed, K. 2004. Hurst Exponent and Financial Market Predictibility. Proceedings of $2^{\text {nd }}$ IASTED International Conference on Financial Engineering and Applications. Cambridge, MA, USA.

Tagliafichi, R.A. 2003. The Estimation oaf Market Var Using Garch Models and A Heavy Tail Distributions. Argentina : University of Buenos A ires

Paridi. 2019. Perbandingan Metode ARIMA(Box Jenkins), ARFIMA, Regresi Spktral dan SSA dalam Peramalan Jumlah Kasus Demam Berdarah Dengue di Rumah Sakit Hasan Sadikin Bandung. Jurnal Ilmu Sosial dan Ilmu Politik Vol. 2, No. 1 : Hal. 243-258 